\title{
Desain dan Implementasi Smart Home Konsumsi Daya Rendah Menggunakan Algoritma Optimisasi Cuckoo- Earthworm
}

\author{
Miftahul Falahi Alfafa dan Yusuf Bilfaqih \\ Departemen Teknik Elektro, Institut Teknologi Sepuluh Nopember (ITS) \\ e-mail: bilfaqih@ee.its.ac.id
}

\begin{abstract}
Abstrak-Penggunaan energi merupakan hal yang paling penting pada sistem smart home, karena dengan energi yang kecil maka sistem smart home akan semakin efisien dan juga ekonomis. Konsumsi energi pada sistem smart home dioptimalkan dengan teknik penjadwalan peralatan secara real time berdasarkan harga listrik pada saat itu dan persentase kenyamanan pengguna dimana konsumsi daya setiap peralatan diatur untuk melakukan penghematan. Melalui pendekatan ini pengguna dapat menentukan tingkat kenyamanan secara fleksibel untuk melakukan penghematan tanpa mengurangi kenyamanan yang diperoleh dari setiap peralatan rumah tangga. Algoritma Cuckoo-Earthworm digunakan untuk proses penjadwalan peralatan secara real time. Sistem smart home dilengkapi dengan Raspberry Pi3 sebagai HUB controller dan Smart Plug yang digunakan untuk monitor energi yang digunakan pada setiap peralatan dan juga sebagai switch untuk melakukan penjadwalan. Komunikasi antara HUB controller dan setiap device menggunakan jaringan Z-Wave. Untuk user interface menggunakan Home Assistant. Pada implemetasi sistem smart home dengan daya rendah menggunakan algoritma Cuckoo-Eartworm kali ini didapatkan pengurangan biaya mencapai $41.39 \%$ dan energi mencapai $32.52 \%$ dari peralatan yang tidak terjadwal pada tingkat kenyamanan terendah.
\end{abstract}

Kata Kunci-Smart Home, Optimisasi, Cuckoo-Earthworm, Smart Plug, Raspberry Pi3, Z-Wave, Home Assistant.

\section{PENDAHULUAN}

$\mathrm{P}$ ENGGUNAAN sistem smart home sudah menjadi tren untuk era digital seperti sekarang ini. Dengan adanya sistem smart home maka pengontrolan dan monitoring penggunaan peralatan rumah tangga menjadi sangat mudah karena bisa dilakukan dimana saja dan kapan saja. Namun sistem smart home biasa hanya bisa mempermudah pengguna dalam hal pengontrolan dan monitoring peralatan rumah tangga saja tanpa bisa melakukan optimasi pada energi listrik yang dikonsumsi secara otomatis akibatnya pengaturan kebutuhan konsumsi energi listrik masih bergantung pada pengguna. Oleh karena itu implementasi smart home yang bisa melakukan optimasi energi secara otomatis pada sisi pengguna merupakan hal yang sangat penting karena bisa menghemat pemakaian energi dan juga pengeluaran biaya yang harus dibayarkan. Demand Response (DR) merupakan solusi paling efektif dalam optimasi energi pada sisi pengguna [1]. Demand pada sisi pengguna akan naik seiring dengan meningkatnya produk elekronik pintar yang digunakan di rumah tangga [2], [3]. Optimisasi energi pada sisi pengguna juga dapa dilakukan dengan memberikan reward jika mengurangi pemakaian daya pada saat on-peak [4] dan juga optimisasi energi menggunakan teknik penjadwalan yang disertai dengan koordinasi antar peralatan rumah tangga menggunakan Game Theory (GT) dengan berbagai macam algoritma optimisasi [5]-[7]. Telah dilakukan simulasi dan perbandingan tingkat efisiensi penggunaan beberapa algoritma yang bisa digunakan untuk menghemat energi secara otomatis pada sistem smart grid [8]. Optimisasi beban pada smart grid juga dilakukan dengan algoritma optimisasi Knapsack dan Particle Swarm Optimization (PSO) yang dikombinasikan dengan skema pembayaran Time of Use (TOU) dan Real Time Pricing (RTP) [9]. Demand Side Management pada smart grid juga bisa dilakukan menggunakan Linear Programming dan Genetic Algorithm [10][11]. Penjadwalan pada peralatan rumah tangga juga bisa dilakukan dengan algoritma Cuckoo Search (CS) dan Earthworm Optimization (EWO) dan juga algoritma optimisasi hybrid Cuckoo-Earthworm [12][13][14][15]. Komunikasi antar peralatan pada smart home bisa dilakukan menggunakan media wireless dengan protokol Zigbee atau Z-Wave [16].

\section{SCHEDULING TECHNIQUES}

Terdapat dua macam manajemen energi untuk menghemat pemakaian energi yaitu SSM (Supply Side Management) dan DSM (Demand Side Management). Yang termasuk dalam SSM yaitu instalasi atau penambahan sumber energi baru, akan tetapi penambahan sumber energi baru tentu saja membutuhkan waktu yang relative lama untuk siap dipakai. Dalam DSM, permintaan kebutuhan energi dapat diatur dengan strategi pengaturan pemakaian peralatan yang dibagi menjadi tiga yaitu Load shifting, Valley filling dan Flexible load. Load shifting merupakan manajemen energi yang paling efisien [8]. Strategi Load shifting kebanyakan diimplementasikan dengan DR (Demand Response) program. DR program adalah perubahan penggunaan energi listrik sebagai respon dari perubahan harga listrik yang dikirim oleh utility (sumber energi listrik). DR program dibagi menjadi dua tipe yaitu IDR (Incentive-based DR program) dan PDR (Priced-based DR program). Price signal yang umum dipakai pada PDR yaitu RTP (Real Time Pricing), DAP (Day Ahead Pricing), TOU (Time of Use), dan IBR (Inclined Block Rate). RTP dikenal sebagai pricing scheme yang paling efisien [8]. Sebagai pertimbangan tingkat efisiensi maka digunakan DSM dengan menggunakan program Load shifting dan RTP. 


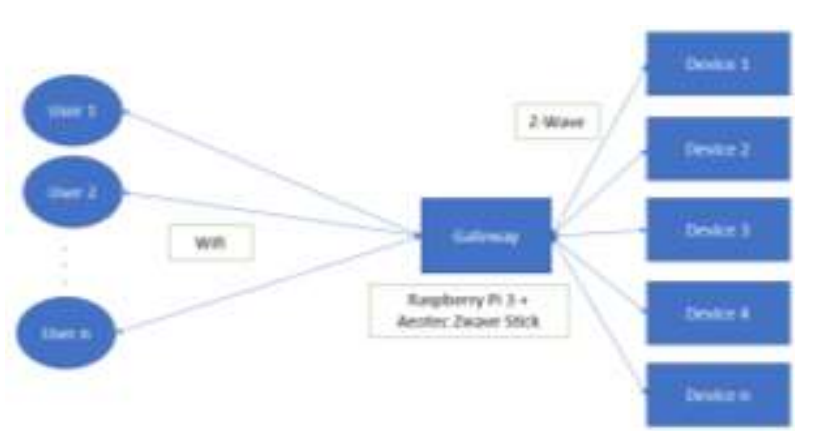

Gambar 1. Sistem keseluruhan smart home

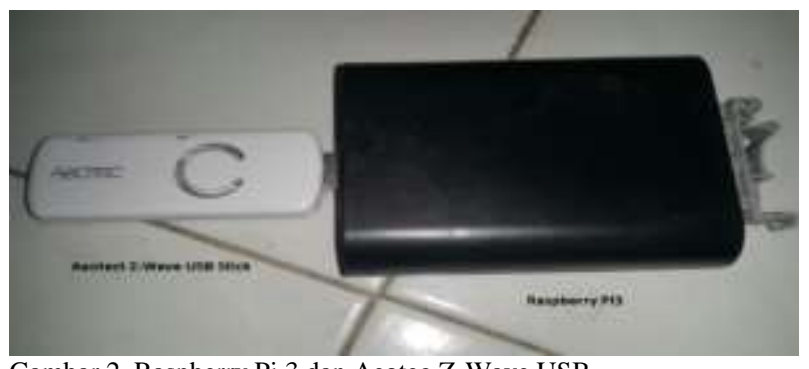

Gambar 2. Raspberry Pi 3 dan Aeotec Z-Wave USB

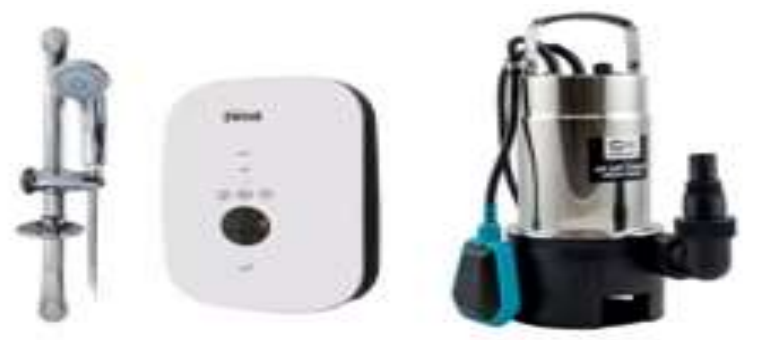

Gambar 3. Water heater and Water pump

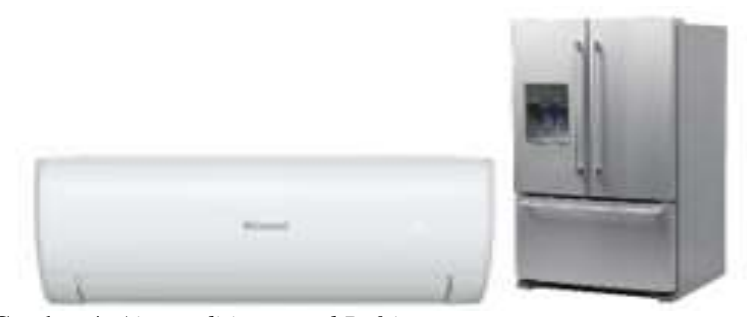

Gambar 4. Air conditioner and Refrigerator

\section{PERANCANGAN SISTEM SMART HOME}

Pada perancangan sistem smart home daya rendah dibagi menjadi 2 yaitu perancangan konsep (untuk analisis perbandingan penggunaan tanpa dan dengan smart home daya rendah) dan perancangan detail. Perancangan detail meliputi perancangan hardware dan software. Sebuah metode Load shifting $s_{1}, s_{2}, \ldots, s_{n}=$ CuckooEarthworm $\left(f\left(s_{1}, s_{2}, \ldots, s_{n}\right)=\right.$ threshold $\left.)\right)$ diberikan sebagai status dari seluruh device (on/off), dalam hal ini dipakai 5 device dengan spesifikasi yang berbeda. Tujuan dari Load shifting adalah menentukan device mana saja yang harus on atau off berdasarkan tarif listrik dan tingkat kenyamanan pengguna. Setiap device dalam rumah tangga pasti memakai daya listrik dengan kapasitas tertentu. Sehingga model energi dan biaya yang dipakai dari setiap device adalah sebagai berikut:

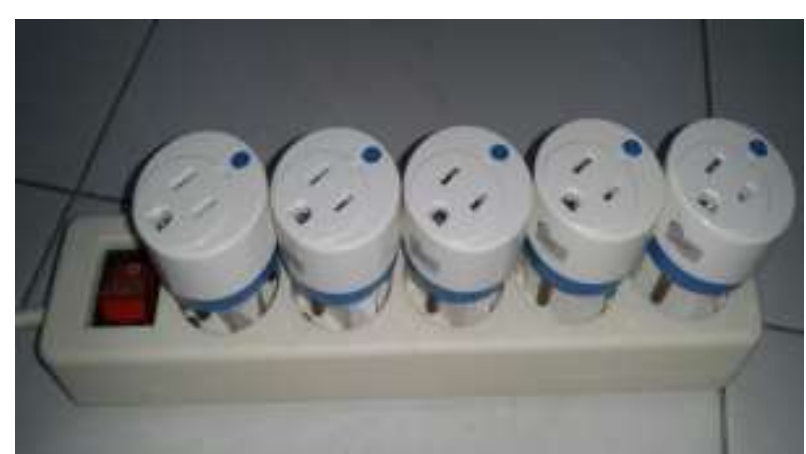

Gambar 5. Z-Wave Smart Plug Neo Coolcam
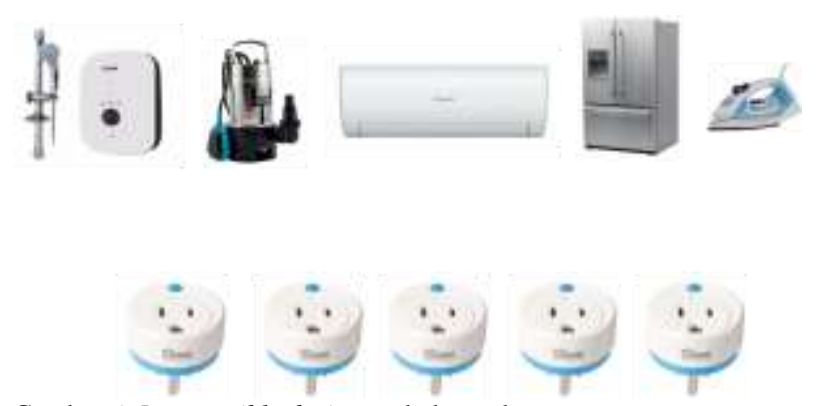

Gambar 6. Interruptible devices terhubung dengan

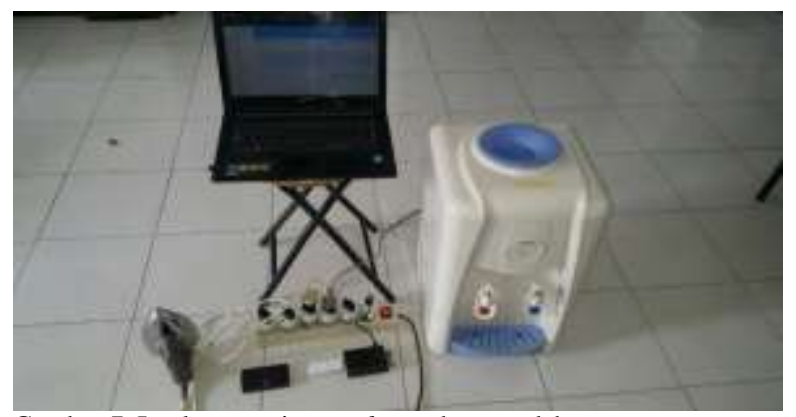

Gambar 7. Implementasi smart home daya rendah

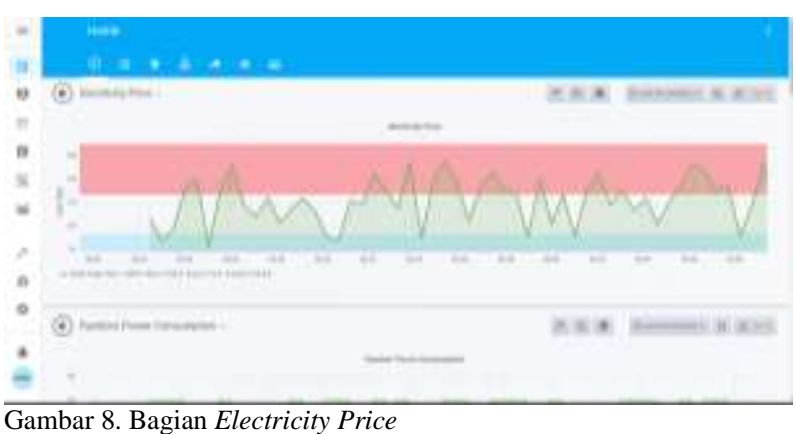

$$
\begin{aligned}
& \text { Fungsi }_{\text {objektif }}=\sum_{t=1}^{24}\left\{\left(\sum_{i=1}^{n} s_{i(t)} * \text { power }_{i(t)}\right.\right. \\
& \text { tarif } \left.\left._{\text {listrik }(t)}\right)- \text { threshold }\right\}
\end{aligned}
$$

\section{A. Perancangan Sistem}

Pada sistem smart home daya rendah terdapat beberapa variable yang diperlukan untuk mengoptimasi energi dan biaya listrik berdasarkan tarif listrik dan tingkat kenyaman pengguna yaitu

\section{1) Menentukan Random Energy Consumption}

Random energy consumption digunakan untuk perbandingan tanpa menggunakan optimasi energi dan biaya.

$$
\begin{gathered}
\text { device }_{\text {random }_{i}}=\text { rand }_{\text {binary }(t)} * \text { power }_{i(t)} \\
\text { unoptimized }_{\text {energy }}=\sum_{i=1}^{i=n} \text { device }_{\text {random }_{i}}
\end{gathered}
$$



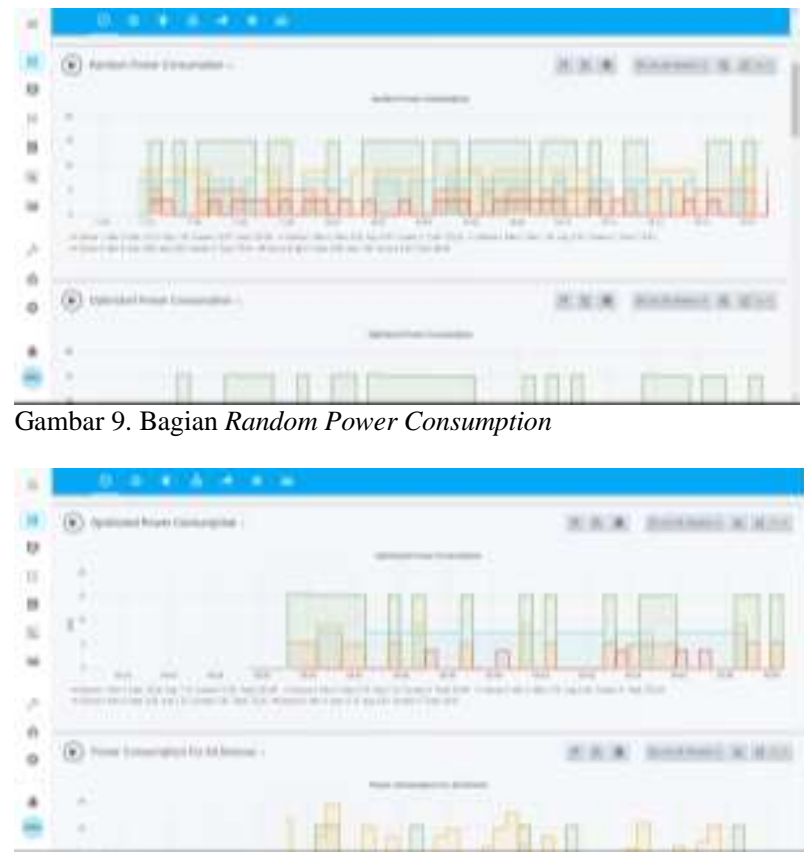

Gambar 10. Bagian Optimized Power Consumption

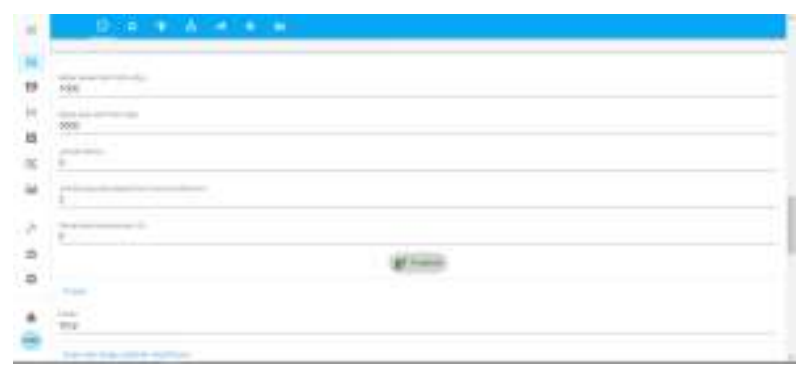

Gambar 11. Bagian pengaturan untuk algoritma

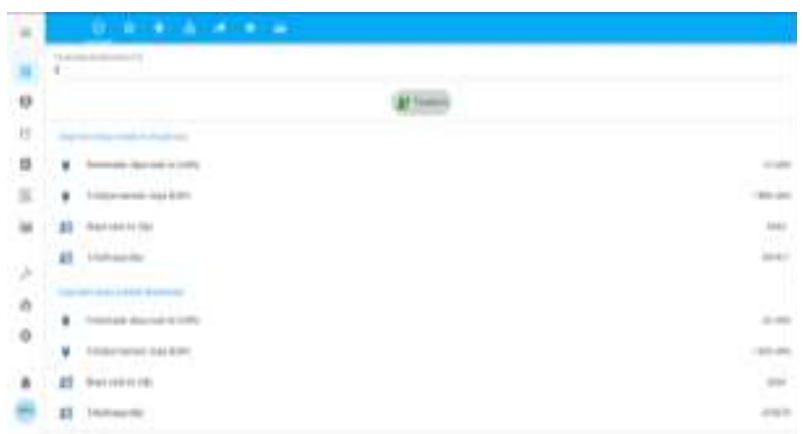

Gambar 12. Bagian Input Persentase kenyamanan dan monitor energi dan biaya sebelum dan sesudah dioptimasi

Total energy dalam 1 hari yaitu:

$$
\text { total }_{\text {energy }}=\sum_{t=1}^{24} \text { unoptimized }_{\text {energy }_{i}}
$$

\section{2) Menentukan Optimized Power Consumption}

Optimized Power Consumption didapat dengan mencari nilai threshold yang kemudian dimasukkan ke algoritma Cuckoo-Earthworm untuk mendapatkan status dari masingmasing peralatan (on atau off). Untuk mencari nilai threshold dilakukan langkah-langkah sebagai berikut:

$$
\begin{gathered}
\text { device }_{i}=\text { power }_{i(t)} * \operatorname{tarif}_{\text {listrik }(t)} \\
\text { total }_{\text {biaya }}=\sum_{i=1}^{n} \text { device }_{i}
\end{gathered}
$$

Menentukan nilai threshold dipengaruhi dari persentase alokasi dari harga listrik dan persentase kenyamanan. Untuk tugas akhir kali ini persentase alokasi dari harga listrik dibagi
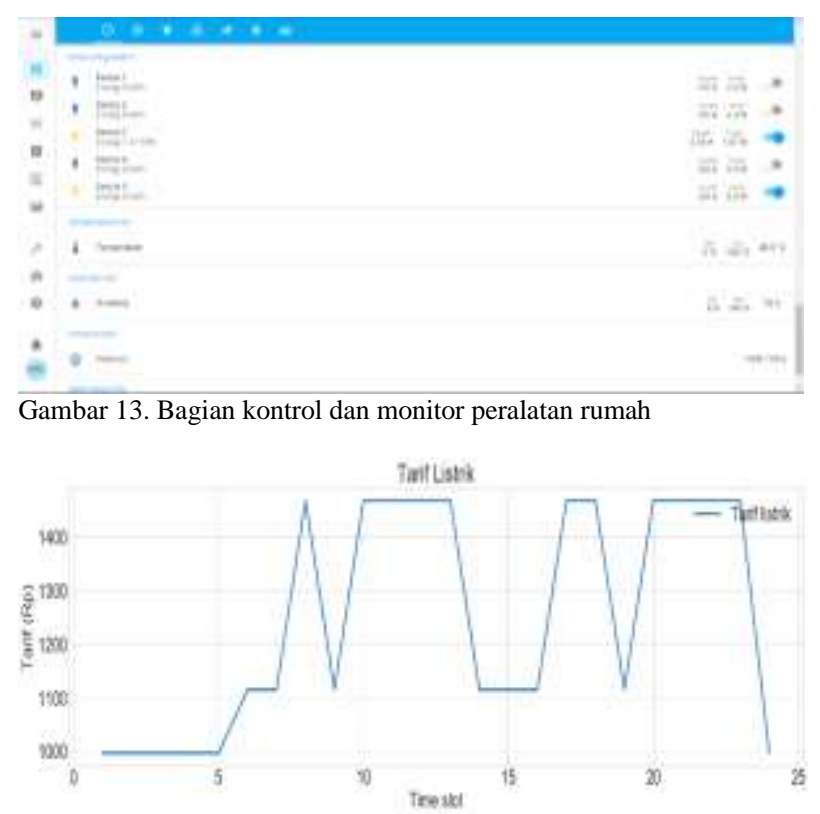

Gambar 14. Real Time Pricing

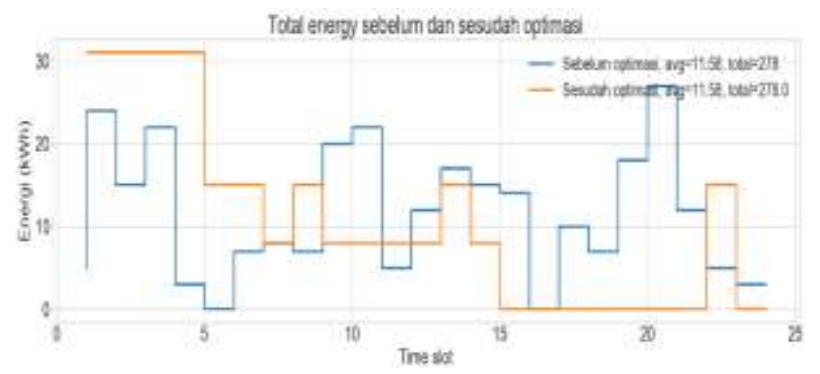

Gambar 15. Pemakaian energi dalam 1 hari

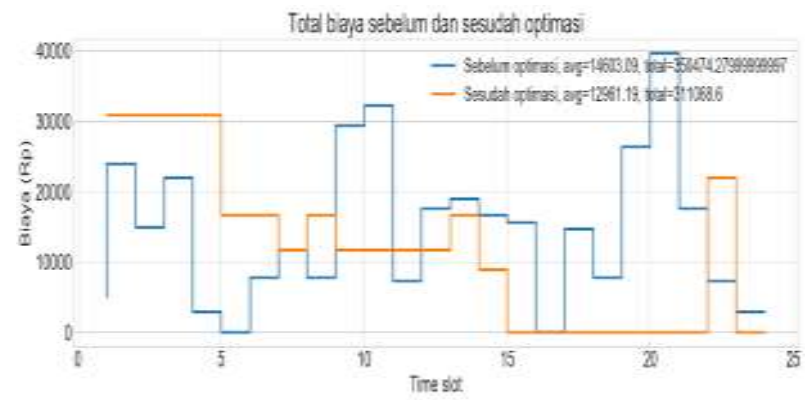

Gambar 16. Total biaya dalam 1 hari

3 yaitu Low price (80\%), Med price (53.33\%) dan High price (26.67\%). Dan untuk persentase kenyamanan bernilai 0\% s/d $100 \%$. Sehingga nilai threshold didapat dengan persamaan sebagai berikut:

$$
y \%=\frac{x-a}{b-a} *(b-a) *(d-c)+c
$$

Dimana:

$\mathrm{y} \%=$ nilai threshold

$\mathrm{x}=$ persentase kenyaman $(\%)$

$\mathrm{a}=$ batas bawah persentase kenyamanan (\%)

$\mathrm{b}=$ batas atas persentase kenyamanan $(\%)$

$\mathrm{c}=$ batas bawah persentase alokasi harga listrik (\%)

$\mathrm{d}=$ batas atas persentase alokasi dari harga listrik (\%), maka nilai threshold yaitu:

threshold=y\%*total_biaya 


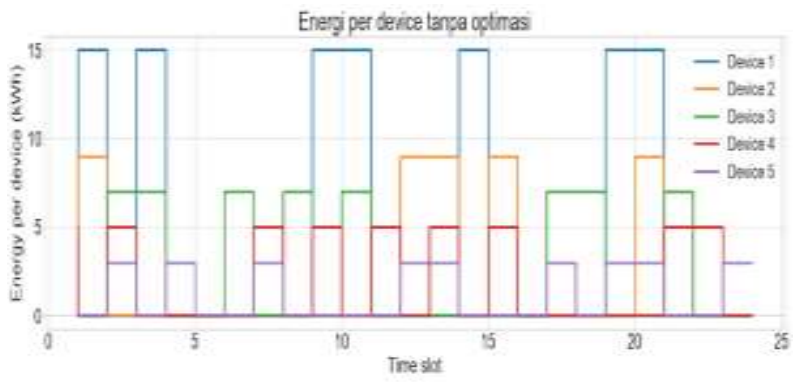

Gambar 17. Energi per device sebelum dioptimasi

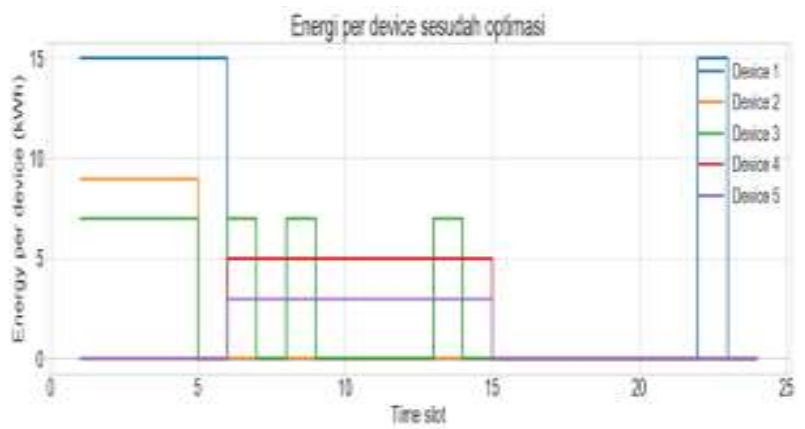

Gambar 18. Energi per device sesudah dioptimasi

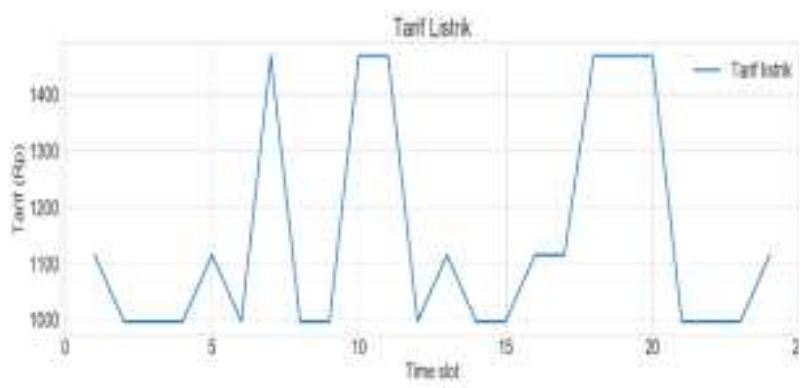

Gambar 19. Real Time Pricing

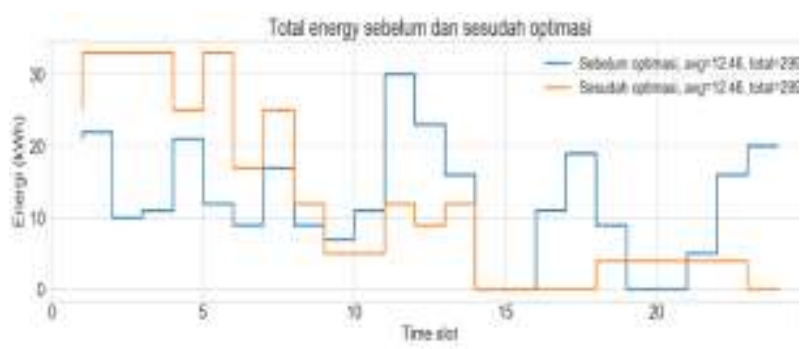

Gambar 20. Pemakaian energi dalam 1 hari

Menentukan status masing-masing peralatan berdasarkan nilai threshold dengan menggunakan algoritma optimisasi Cuckoo-Earthworm. Fungsi objektif yang digunakan pada algoritma Cuckoo-Earthworm adalah sebagai berikut:

$$
\begin{gathered}
\text { status }_{i}=\operatorname{power}_{i(t)} * \operatorname{tarif}_{\text {listrik }(t)} * s_{i(t)} \\
f\left(s_{1}, s_{2}, \ldots, s_{n}\right)=\left(\sum_{i=1}^{n} s_{i(t)} * \operatorname{power}_{i(t)} * \operatorname{tarif}_{\text {listrik }(t)}\right) \\
f\left(s_{1}, s_{2}, \ldots, s_{n}\right)<=\text { threshold }
\end{gathered}
$$

$s_{1}, s_{2}, \ldots, s_{n}=$ CuckooEarthworm $\left(f\left(s_{1}, s_{2}, \ldots, s_{n}\right)=\right.$ threshold))

Dimana:

$S_{1}=$ status peralatan $1(0 / 1)$

$s_{2}=$ status peralatan $2(0 / 1)$

$s_{n}=$ status peralatan ke-n $(0 / 1)$

Sehingga Optimized Energy Consumption dapat dicari dengan persamaan sebagai berikut:
Tabel 1.

\begin{tabular}{|c|c|c|c|}
\hline Device & Output & $\begin{array}{l}\text { Konsumsi } \\
\text { Daya }\end{array}$ & $\begin{array}{l}\text { Operational } \\
\text { Time (Hour) }\end{array}$ \\
\hline Water heater & $20^{\circ} \mathrm{C}-60^{\circ} \mathrm{C}$ & $\begin{array}{l}15 \mathrm{~kW}-20 \\
\mathrm{~kW}\end{array}$ & 5 \\
\hline Water pump & $\begin{array}{l}1 \text { liter } / \mathrm{min} \text { - } \\
3 \text { liter/min }\end{array}$ & $9 \mathrm{~kW}-13 \mathrm{~kW}$ & 7 \\
\hline Air Conditioner & $26^{\circ} \mathrm{C}-22^{\circ} \mathrm{C}$ & $7 \mathrm{~kW}-9 \mathrm{~kW}$ & 8 \\
\hline Refrigerator & $15^{\circ} \mathrm{C}-0{ }^{\circ} \mathrm{C}$ & $5 \mathrm{~kW}-8 \mathrm{~kW}$ & 9 \\
\hline Iron & $\begin{array}{l}90{ }^{\circ} \mathrm{C}-120 \\
{ }^{\circ} \mathrm{C}\end{array}$ & $3 \mathrm{~kW}-7 \mathrm{~kW}$ & 9 \\
\hline
\end{tabular}

Spesifikasi output, jumlah konsumsi daya dan operational time pada interruptible devices

Tabel 2.

\begin{tabular}{|c|c|c|c|}
\hline $\begin{array}{l}\text { Persentase } \\
\text { kenyamanan } \\
(\%)\end{array}$ & $\begin{array}{l}\text { Jumlah } \\
\text { populasi }\end{array}$ & $\begin{array}{l}\text { Penggunaan total } \\
\text { energi }(\mathrm{kWh})\end{array}$ & $\begin{array}{l}\text { penghematan total } \\
\text { biaya }(\%)\end{array}$ \\
\hline 0 & 3 & 278 & 7.93 \\
\hline 0 & 10 & 278 & 11.24 \\
\hline 0 & 20 & 278 & 5.17 \\
\hline 0 & 30 & 278 & 8.11 \\
\hline 30 & 3 & 299 & 6.4 \\
\hline 30 & 10 & 299 & 4.1 \\
\hline 30 & 20 & 299 & 9.73 \\
\hline 30 & 30 & 299 & 4.92 \\
\hline 60 & 3 & 344 & 6.41 \\
\hline 60 & 10 & 344 & 9.72 \\
\hline 60 & 20 & 344 & 5.97 \\
\hline 60 & 30 & 344 & 0.14 \\
\hline 100 & 3 & 412 & 5.99 \\
\hline 100 & 10 & 412 & 2.91 \\
\hline 100 & 20 & 412 & 6.98 \\
\hline 100 & 30 & 412 & 1.82 \\
\hline
\end{tabular}

Hubungan persentase kenyaman dan jumlah populasi dengan persentase penghematan energi dan biaya

$$
\text { optimized }_{\text {energy }}=\sum_{i=1}^{n} s_{i(t)} * \text { power }_{i(t)}
$$

Total energy dalam 1 hari yaitu:

$$
\text { total }_{\text {energy }}=\sum_{t=1}^{24} \text { optimized }_{\text {energy }_{i}}
$$

3) Menentukan Energy Consumption All Devices

Untuk menamplikan total energi keseluruhan dari peralatan sebelum dan sesudah optimasi pada waktu tertentu, persamaan yang digunakan yaitu persamaan (4) dan (14).

4) Menentukan Total Electricity Cost

Total electricity Cost dibagi menjadi 2 yaitu Total Electricity Cost sebelum dan sesudah dioptimasi. Total Electricity Cost sebelum dioptimasi:

device $_{\text {random }(i)}=\operatorname{rand}_{\text {binary }(t)} * \operatorname{power}_{i(t)} *$

tarif $f_{\text {listrik }(t)}$

unoptimized $_{\text {cost }}=\sum_{i=1}^{n}$ device $_{\text {random }(i)}$ 


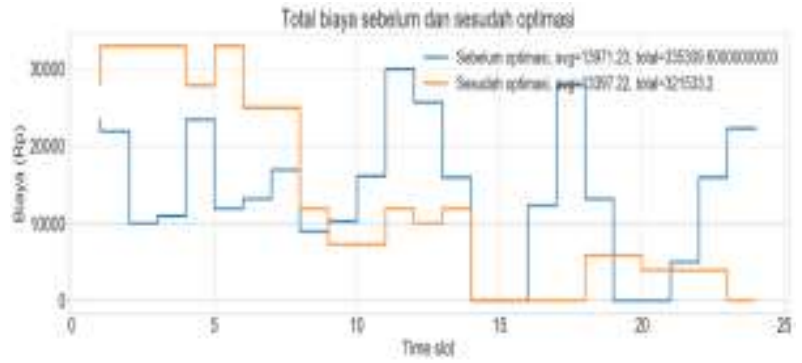

Gambar 21. Total biaya dalam 1 hari

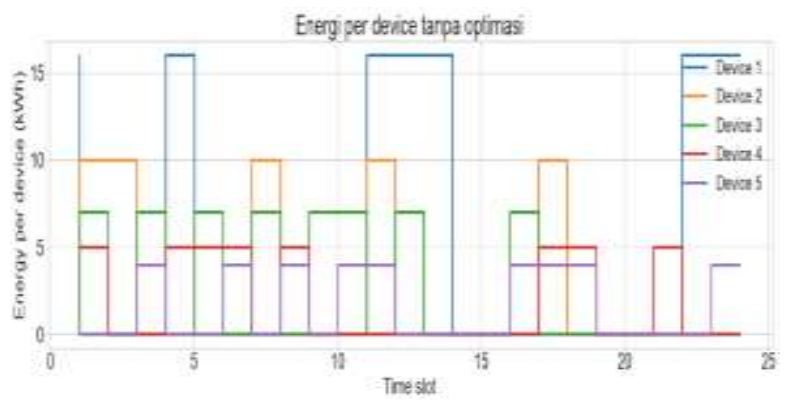

Gambar 22. Energi per device sebelum dioptimasi

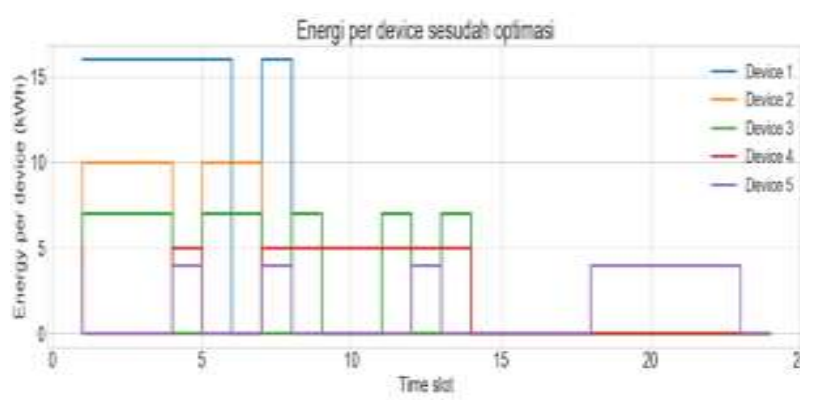

Gambar 23. Energi per device sesudah dioptimasi

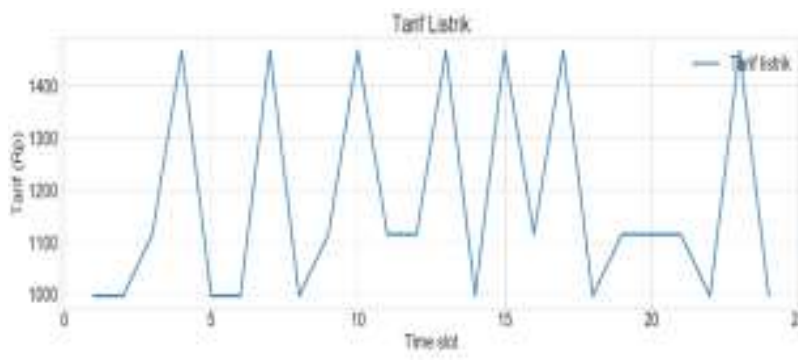

Gambar 24. Real Time Pricing

Total cost dalam 1 hari yaitu:

$$
\text { total }_{\text {cost }}=\sum_{t=1}^{24} \text { unoptimized }_{\text {cost }}{ }_{i}
$$

Total Electricity Cost setelah dioptimasi:

$$
\begin{aligned}
& \text { device }_{i}=s_{i(t)} * \text { power }_{i(t)} * \text { tarif }_{\text {listrik }(t)} \\
& \text { optimized }_{\text {cost }}=\sum_{i=1}^{n} \text { device }_{i}
\end{aligned}
$$

Total cost dalam 1 hari yaitu:

$$
\text { total }_{\text {cost }}=\sum_{t=1}^{24} \text { optimized }_{\text {cost }_{i}}
$$

\section{5) Arsitektur Sistem Smart Home}

Semua peralatan rumah tangga terhubung dengan Z-Wave Smart Plug. User dapat mengontrol dan memonitor semua peralatan rumah tangga melalui smart phone atau tablet PC yang terhubung dengan gateway. User 1, user 2 sampai dengan user ke-n merupakan pengguna atau penghuni smart home. Setiap pengguna dapat mengakses sistem smart home

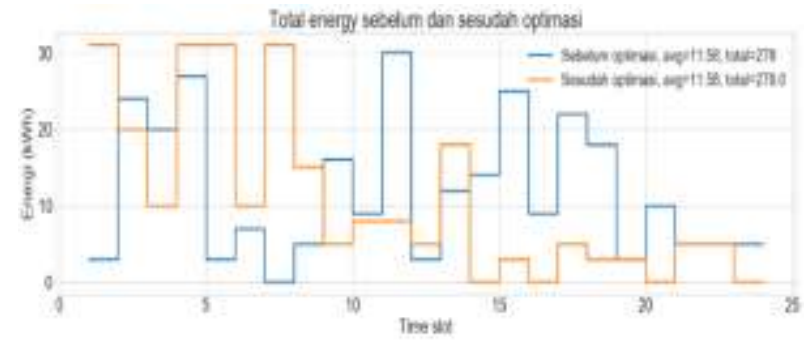

Gambar 25. Pemakaian energi dalam 1 hari

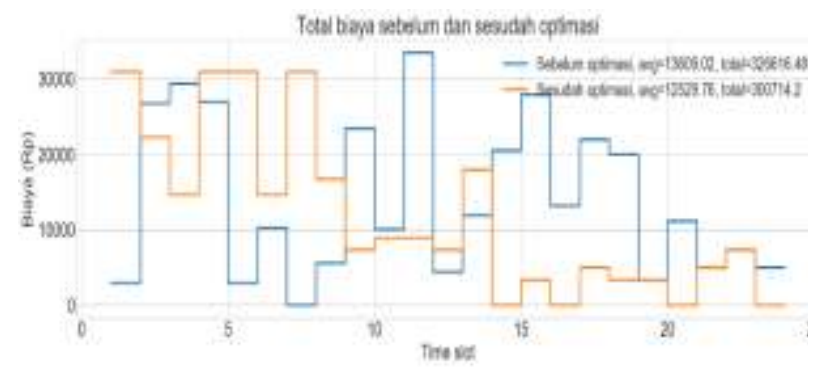

Gambar 26. Total biaya dalam 1 hari

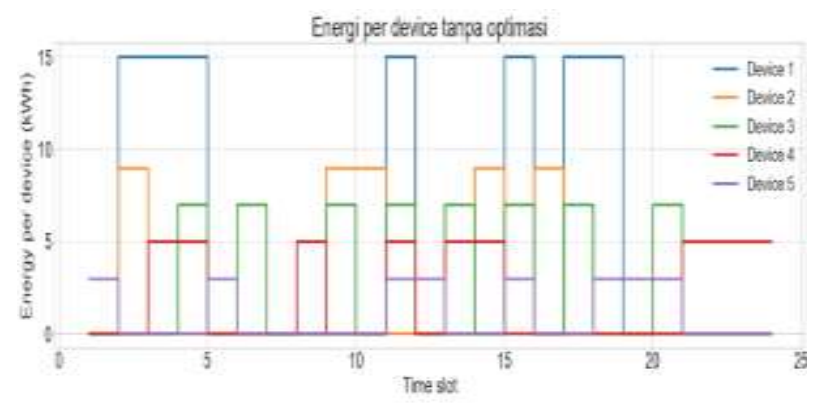

Gambar 27. Energi per device sebelum dioptimasi

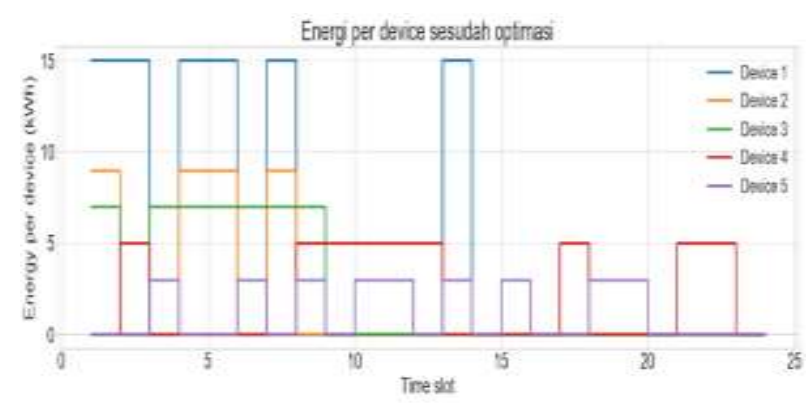

Gambar 28. Energi per device sesudah dioptimasi

menggunakan teknologi Wi-Fi. User dapat memonitor dan mengontrol setiap peralatan rumah tangga melalui Smart Phone, Laptop ataupun Personal Computer. User juga dapat mengontrol tingkat penghematan daya pada setiap peralatan berdasarkan persentase kenyamanan pengguna. Gateway berfungsi untuk menghubungkan semua user dengan setiap peralatan rumah tangga. Komunikasi antara gateway dengan setiap peralatan rumah tangga (device) menggunakan protokol Z-Wave yang merupakan protokol komunikasi dengan penggunaan daya yang sangat hemat. Sistem keseluruhan samart home dapat dilihat pada Gambar 1.

\section{B. Perancangan Hardware}

Terdapat beberapa komponen yang digunakan pada sistem smart home yaitu Raspberry Pi3, Z-Wave Smart Plug Neo Coolcam, Aeotec Z-Wave USB Stick dapat dilihat pada Gambar 2, Mifi dan 5 buah interruptible devices. Raspberry Pi3 digunakan sebagai kontroler, Z-Wave USB Stick sebagai 


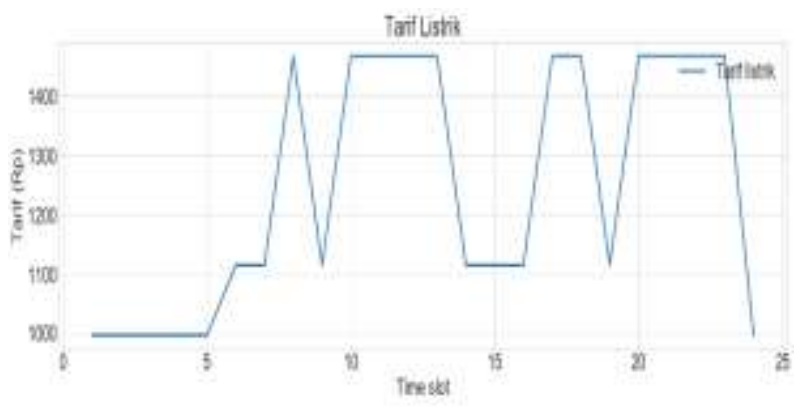

Gambar 29. Real Time Pricing

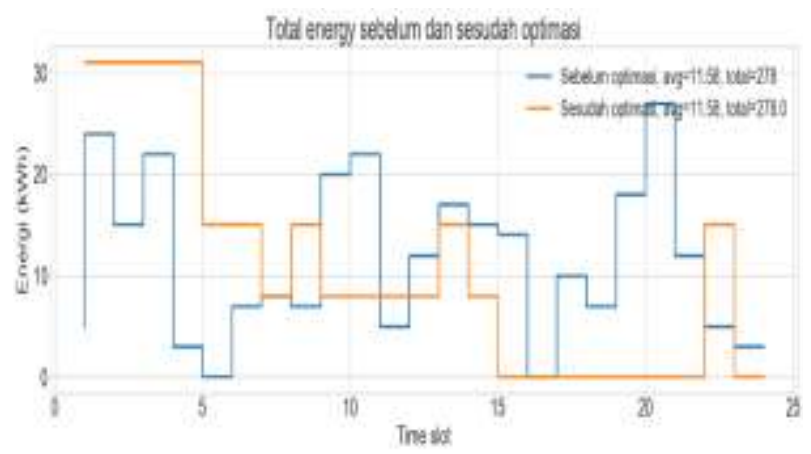

Gambar 30. Pemakaian energi dalam 1 hari

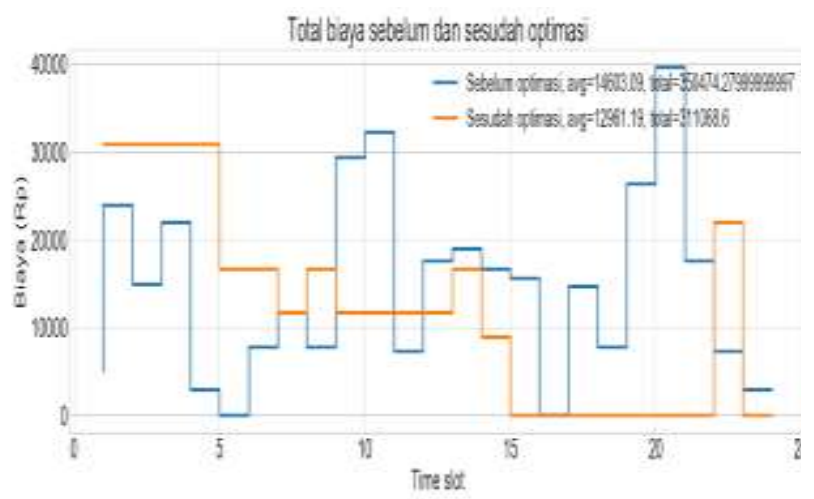

Gambar 31. Total biaya dalam 1 hari

gateway, Z-Wave Smart Plug Neo Coolcam dapat dilihat pada Gambar 5 digunakan untuk monitor dan kontrol dari berbagai peralatan rumah tangga, Mifi sebagai media komunikasi antara user dengan sistem smart home dan interruptible devices digunakan untuk mewakili beban dari peralatan rumah tangga. Water heater and Water Pump dapat dilihat pada Gambar 3, Air conditioner and Refrigator dapat dilihat pada Gambar 4.Dalam tugas akhir kali ini digunakan 5 buah Neo Coolcam dan 5 interruptible devices meliputi water heater, water pump, air conditioner, refrigerator, iron dengan spesifikasi daya yang berbeda- beda. Spesifikasi dari Aeotec Z-ZWave USB Stick yang digunakan yaitu: (1)USB 2.0 compliant; (2)Operating distance: up to 500 feet/150 metres outdoors in normal mode or 1310 feet/400 metres outdoors in PA mode; (3)Radio protocol Z-Wave; (4)Radio Frequency $908.4 \mathrm{MHz}$. Spesifikasi dari Smart Plug Z-Wave Neo Coolcam yaitu: (1)Input voltage: 110-230V AC 50/60Hz; (2)Max current: 13A; (3)Radio protocol: Z-Wave; (4)Radio frequency: $908.4 \mathrm{MHz}$; (5)Wireless distance: up to $60 \mathrm{~m}$ outdoor, up to 40m indoor. Spesifikasi interruptible devices dapat dilihat pada Tabel 1. Dalam tugas akhir ini, semakin besar tingkat kenyamanan pengguna maka semakin efisien

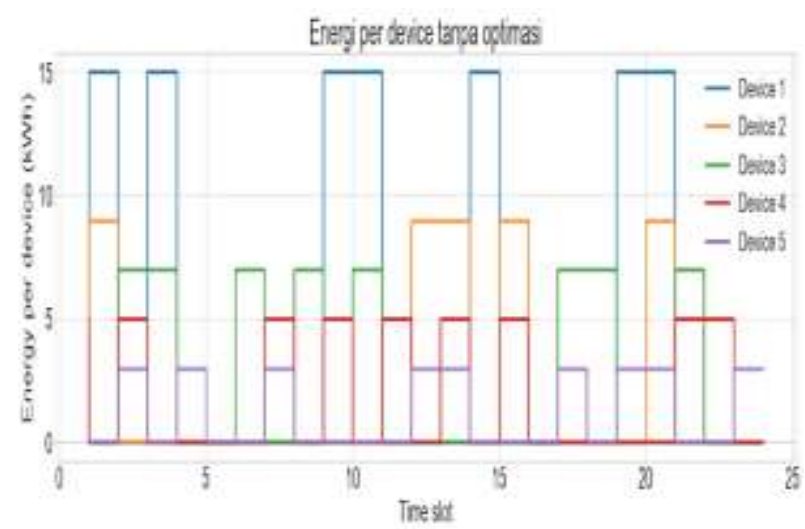

Gambar 32. Energi per device sebelum dioptimasi

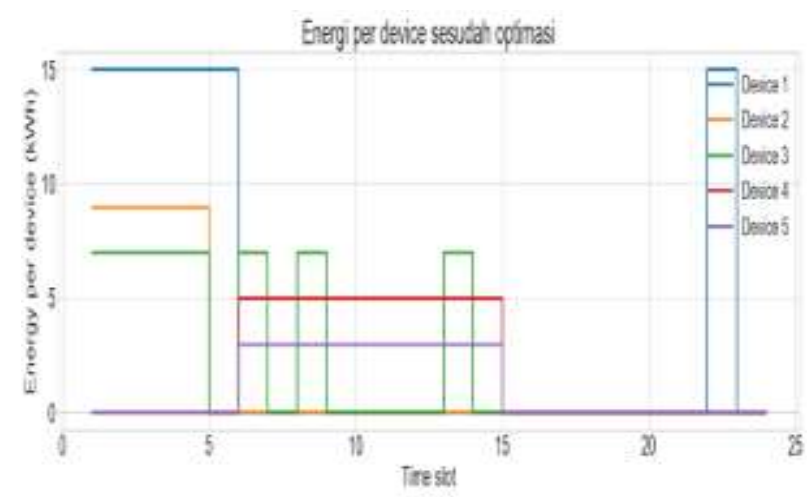

Gambar 33. Energi per device sesudah dioptimasi

pula daya yang dikonsumsi oleh masing-masing device untuk memberikan kenyamanan kepada pengguna. Interruptible devices terhubung dengan smart plug dapat dilihat pada Gambar 6. Implementasi smart home daya rendah dapat dilihat pada Gambar 7.

\section{Perancangan Software User Interface}

Aplikasi yang digunakan untuk smart home yaitu Home Assistant yang dibuat dengan menggunakan Bahasa pemrograman Python. Dalam aplikasi smart home terdapat beberapa bagian utama yaitu:

1) Electricity Price

Digunakan untuk menampilkan grafik perubahan harga listrik secara real time dari waktu ke waktu dapat dilihat pada Gambar 8.

\section{2) Random Energy Consumption}

Digunakan untuk menampilkan grafik konsumsi energi listrik dari waktu ke waktu tanpa adanya optimasi pemakaian energi listrik berdasarkan harga listrik pada masing-masing peralatan dapat dilihat pada Gambar 9.

3) Optimized Energy Consumption

Digunakan untuk menampilkan grafik konsumsi energi listrik dari waktu ke waktu setelah dilakukan optimasi terhadap pemakaian energi listrik berdasarkan harga listrik dan tingkat kenyamanan pengguna pada masing-masing peralatan dapat dilihat pada Gambar 10.

4) Energy Consumption for All Devices

Digunakan untuk menampilkan grafik konsumsi energi listrik dari waktu ke waktu untuk seluruh peralatan.

5) Total Electricity Cost

Digunakan untuk menampilkan grafik tagihan biaya listrik dari waktu ke waktu untuk seluruh peralatan. 


\section{6) Pengaturan untuk Alogaritma}

Digunakan untuk keperluan testing algoritma, untuk input parameter jumlah device, populasi, batas bawah dan atas tarif listrik dapat dilihat pada Gambar 11.

7) Input Persentase Kenyamanan

Digunakan untuk memasukkan tingkat kenyamanan pengguna (dalam persen)

8) Monitor Energi dan Biaya sebelum Dioptimasi

Digunakan untuk menampilkan penggunaan energi saat ini, total energi, biaya listrik saat ini dan total biaya listrik sebelum dioptimasi.

9) Monitor energi dan biaya setelah dioptimasi

Digunakan untuk menampilkan penggunaan energi saat ini, total energi, biaya listrik saat ini dan total biaya listrik setelah dioptimasi dapat dilihat pada Gambar 12.

10) Kontrol dan monitor 5 peralatan rumah tangga Digunakan untuk monitoring energi dan status (on/off) pada masing-masing peralatan dan juga sebagai kontrol manual ke peralatan rumah tangga dapat dilihat pada Gambar 13.

\section{PENGUJIAN DAN ANALISIS}

Bab ini membahas hasil simulasi dari sistem smart home daya rendah dengan teknik penjadwalan peralatan rumah tangga. Hasil dari optimasi berupa keluaran energi pemakaian dan tarif listrik yang harus dibayar berdasarkan perubahan tarif listrik secara real time dan persentase kenyamanan pengguna. Tarif listrik berubah setiap menit dengan nilai random berupa tiga variasi nilai yaitu $\mathrm{Rp} 997, \mathrm{Rp} 1.115$, dan Rp 1.467,52. Berikut ini merupakan grafik tarif listrik yang berubah setiap 1 menit.

\section{A. Pengujian terhadap Tingkat Kenyamanan}

Berikut ini merupakan pengujian dan analisis hubungan konsumsi energi listrik dan biaya yang harus dibayarkan untuk sebelum dan sesudah dioptimasi terhadap tingkat kenyamanan pengguna (semakin tinggi persentase kenyamanan maka probabilitas peralatan dapat digunakan sewaktu-waktu akan semakin tinggi).

1) Persentase Kenyamanan $=0 \%$, Jumlah Populasi $=10$

Pemakaian energi listrik dan beban biaya sebelum dilakukan optimasi didapatkan data sebagai berikut; (1)Total pemakaian energi: $278 \mathrm{kWh}$; (2)Rata-rata pemakaian energi: 11.58 kWh; (3)Total biaya: Rp. 350,474.27; (4)Rata-rata biaya: Rp. 14,603.09. Pemakaian energi listrik dan beban biaya sesudah dilakukan optimasi dengan Teknik penjadwalan peralatan didapatkan data sebagai berikut; (1)Total pemakaian energi: $278 \mathrm{kWh}$; (2)Rata-rata pemakaian energi: $11.58 \mathrm{kWh}$; (3)Total biaya: Rp. 311,068.6; (4)Rata-rata biaya: Rp. 12,961.19. Dari data yang diperoleh terjadi penghematan pada total biaya yaitu sebesar $11.24 \%$. Real Time Pricing dapat dilihat pada Gambar 14. Pemakaian energi dalam 1 hari dapat dilihat pada Gambar 15. Total biaya dalam 1 hari dapat dilihat pada Gambar 16. Energi per device sebelum dioptimasi dapat dilihat pada Gambar 17. Energi per device sesudah dioptimasi dapat dilihat pada Gambar 18 .

2) Persentase Kenyamanan $=30 \%$, Jumlah Populasi $=10$

Pemakaian energi listrik dan beban biaya sebelum dilakukan optimasi didapatkan data sebagai berikut; (1)Total pemakaian energi: $299 \mathrm{kWh}$; (2)Rata-rata pemakaian energi: 12.46 kWh; (3)Total biaya: Rp. 335,309.6; (4)Rata-rata biaya: Rp. 13,971.23. Pemakaian energi listrik dan beban biaya sesudah dilakukan optimasi dengan Teknik penjadwalan peralatan didapatkan data sebagai berikut; (1)Total pemakaian energi: $299 \mathrm{kWh}$; (2)Rata-rata pemakaian energi: $12.46 \mathrm{kWh}$; (3)Total biaya: Rp. 321,533.2; (4)Rata-rata biaya: Rp. 13,397.22. Dari data yang diperoleh terjadi penghematan pada total biaya yaitu sebesar $4.1 \%$ dan kenaikan pemakaian total energi sebesar $7 \%$ dari tingkat kenyamanan 0\%. Real Time Pricing dapat dilihat pada Gambar 19. Pemakaian energi dalam 1 hari dapat dilihat pada Gambar 20. Total biaya dalam 1 hari dapat dilihat pada Gambar 21. Energi per device sebelum dioptimasi dapat dilihat pada Gambar 22. Energi per device sesudah dioptimasi dapat dilihat pada Gambar 23

\section{B. Pengujian terhadap Jumlah Populasi}

Berikut ini merupakan pengujian dan analisis hubungan konsumsi energi listrik dan biaya yang harus dibayarkan untuk sebelum dan sesudah dioptimasi terhadap jumlah populasi pada algoritma Cuckoo-Earthworm.

1) Persentase Kenyamanan $=0 \%$, Jumlah Populasi $=3$

Pemakaian energi listrik dan beban biaya sebelum dilakukan optimasi didapatkan data sebagai berikut; (1)Total pemakaian energi: $278 \mathrm{kWh}$; (2)Rata-rata pemakaian energi: 11.58 kWh; (3)Total biaya: Rp. 326,616.4; (4)Rata-rata biaya: Rp. 13,609.02. Pemakaian energi listrik dan beban biaya sesudah dilakukan optimasi dengan Teknik penjadwalan peralatan didapatkan data sebagai berikut; (1)Total pemakaian energi: $278 \mathrm{kWh}$; (2)Rata-rata pemakaian energi: $11.58 \mathrm{kWh}$; (3)Total biaya: Rp. 300,714.2; (4)Rata-rata biaya: Rp. 12,529.76. Dari data yang diperoleh terjadi penghematan pada total biaya yaitu sebesar $7.93 \%$. Real Time Pricing dapat dilihat pada Gambar 24. Pemakaian energi dalam 1 hari dapat dilihat pada Gambar 25. Total biaya dalam 1 hari dapat dilihat pada Gambar 26. Energi per device sebelum dioptimasi dapat dilihat pada Gambar 27. Energi per device sesudah dioptimasi dapat dilihat pada Gambar 28.

2) Persentase Kenyamanan $=0 \%$, Jumlah Populasi $=10$

Pemakaian energi listrik dan beban biaya sebelum dilakukan optimasi didapatkan data sebagai berikut: (1)Total pemakaian energi: $278 \mathrm{kWh}$; (2)Rata-rata pemakaian energi: 11.58 kWh; (3)Total biaya: Rp. 350,474.27; (4)Rata-rata biaya: Rp. 14,603.09. Pemakaian energi listrik dan beban biaya sesudah dilakukan optimasi dengan Teknik penjadwalan peralatan didapatkan data sebagai berikut; (1)Total pemakaian energi: $278 \mathrm{kWh}$; (2)Rata-rata pemakaian energi: $11.58 \mathrm{kWh}$;(3)Total biaya: Rp. 311,068.6; (4)Rata-rata biaya: Rp. 12,961.19. Dari data yang diperoleh terjadi penghematan pada total biaya yaitu sebesar $11.24 \%$. Real Time Pricing dapat dilihat pada Gambar 29. Pemakaian energi dalam 1 hari dapat dilihat pada Gambar 30. Total biaya dalam 1 hari dapat dilihat pada Gambar 31. Energi per device sebelum dioptimasi dapat dilihat pada Gambar 32. Energi per device sesudah dioptimasi dapat dilihat pada Gambar 33.

\section{Rangkuman Data Hasil Pengujian}

Berikut ini merupakan rangkuman data hasil pengujian dan analisis hubungan konsumsi energi listrik dan biaya yang harus dibayarkan untuk sebelum dan sesudah dioptimasi terhadap persentase kenyamanan dan jumlah populasi pada algoritma Cuckoo-Earthworm. Hubungan persentase kenyaman dan jumlah populasi dengan persentase penghematan energi dan biaya dapat dilihat pada Tabel 2 . 


\section{KESIMPULAN}

Dari hasil simulasi smart home daya rendah dengan optimasi Cuckoo-Earthworm, dapat diambil beberapa kesimpulan, diantaranya; (1)Banyaknya konsumsi energi dan biaya tagihan listrik dipengaruhi oleh tingkat kenyamanan pengguna, semakin kecil tingkat kenyamanan pengguna maka energi yang dikonsumsi akan semakin sedikit (tingkat penghematan maksimal); (2)Semakin kecil tingkat kenyamanan pengguna maka persentase penghematan energi hasil optimasi terhadap penggunaan energi pada tingkat kenyamanan maksimal (100\%) akan semakin besar; (3)Jumlah populasi pada algoritma Cuckoo-Earthworm mempengaruhi persentase penghematan total biaya; (4)Jumlah optimal populasi pada algoritma CuckooEarthworm untuk memperbesar persentase penghematan total biaya ada di orde puluhan.

Pada tingkat kenyamanan 0\% (tingkat kenyamanan paling rendah), tingkat penghematan total biaya mencapai $41.39 \%$ dan energi mencapai $32.52 \%$ dibandingkan dengan tingkat kenyamanan $100 \%$. Sedangkan tingkat penghematan total biaya terbesar antara sebelum dan sesudah dioptimasi ada di tingkat kenyamanan $0 \%$ dan jumlah populasi 10 dengan penghematan total biaya mencapai $11.24 \%$.

\section{DAFTAR PUSTAKA}

J.S.Vardakas, N.Zorba, and C. Verikoukis, "A Survey on Demand Response Programs in Smart Grids: Pricing Methods and Optimization Algorithms," IEEE Commun. Surv. Tutorials, vol. 17, no. 1, pp. 152-178, 2015.

[2] K. L. Xiang et al., "A Residential End-Use Electric Energy Consumption Model Based on the Development of Household Appliances," in 2017 IEEE Conference on Energy Internet and Energy System Integration, EI2 2017 - Proceedings, 2017, vol. 2018-Janua, pp. 1-5.

A. K. Darmawan, D. Siahaan, T. D. Susanto, Hoiriyah, and B. Umam, "Identifying Success Factors in Smart City Readiness using a Structure Equation Modelling Approach," in Proceedings - 2019 International Conference on Computer Science, Information Technology, and Electrical Engineering, ICOMITEE 2019, 2019, pp. 148-153.

[4] A. Agnetis, G. De Pascale, P. Detti, and A. Vicino, "Load Scheduling for Household Energy Consumption Optimization," IEEE Trans. Smart Grid, vol. 4, no. 4, pp. 2364-2373, Dec. 2013.

[5] A. Jamil, N. Javaid, and S. Aslam, "An Efficient Home Energy Optimization by Using Meta-Heuristic Techniques While Incorporating Game-Theoretic Approach for Real-Time Coordination Among Home Appliances," in 5th International Multi-Topic ICT Conference: Technologies For Future Generations, IMTIC 2018 - Proceedings, 2018, pp. 1-6. [6] R. R. Putri, D. O. Siahaan, and S. Sarwosri, "Peningkatan Akurasi
Estimasi Usaha dan Biaya COCOMO II Berdasarkan Gaussian dan BCO," J. Nas. Tek. Elektro dan Teknol. Inf., vol. 6, no. 3, Sep. 2017.

[7] R. R. Putri, R. Sarno, D. Siahaan, A. S. Ahmadiyah, and S. Rochimah, "Accuracy Improvement of the Estimations Effort in Constructive Cost Model II Based on Logic Model of Fuzzy," Adv. Sci. Lett., vol. 23, no. 3, pp. 2478-2480, 2017.

[8] A. Jamil, N. Javaid, M. U. Khalid, M. N. Iqba, S. Rashid, and N. Anwar, "An Energy Efficient Scheduling of a Smart Home Based on Optimization Techniques," in International Conference on Innovative Mobile and Internet Services in Ubiquitous Computing, Springer, Cham, 2019.

[9] A. Mahmood, N. Javaid, N. A. Khan, and S. Razzaq, "An Optimized Approach for Home Appliances Scheduling in Smart Grid," 2016 19th Int. Multi-Topic Conf., pp. 1-5, 2016.

[10] Z. Zhu, J. Tang, S. Lambotharan, W. H. Chin, and Z. Fan, "An Integer Linear Programming Based Optimization for Home Demand-Side Management in Smart Grid," in 2012 IEEE PES Innovative Smart Grid Technologies, ISGT 2012, 2012, pp. 1-5.

[11] E. Lee and H. Bahn, "A Genetic Algorithm Based Power Consumption Scheduling in Smart Grid Buildings," in
International Conference on Information Networking, 2014, pp. 469-474.

[12] X. B and G. WJ, Innovative Computational Intelligence: A Rough Guide to 134 Clever Algorithms. German: Cham Springer International Publishing, 2014.

[13] N. P. W. Hardy and D. Suwandi, "Penerapan Algoritma Cuckoo Search pada Travelling Salesman Problem," Seminar Nasional Sistem Informasi Indonesia. Medan, 2013., 2013. .

[14] M. Ali et al., "Earth Worm Optimization for Home Energy Management System in Smart Grid," in Lecture Notes on Data Engineering and Communications Technologies book series (LNDECT, volume 12), Springer International Publishing, 2017, pp. 583-596.

[15] G. G. Wang, S. Deb, and L. Dos Santos Coelho, "Earthworm Optimisation Algorithm: A Bio-Inspired Metaheuristic Algorithm for Global Optimisation Problems," Int. J. Bio-Inspired Comput., vol. 12, no. 1, pp. 1-22, 2018.

[16] L. Li, W. Xie, Z. He, X. Xu, C. Chen, and X. Cui, "Design of Smart Home Control System Based on ZigBee and Embedded Web Technology," in Lecture Notes in Computer Science book series (LNCS, volume 7530), Springer, 2012, pp. 67-74. 